\title{
Bioremediation of Crude Oil Polluted Terrestrial Soil using Aspergillus clavatus and Pichia spp.
}

\author{
Salome Ibietela Douglas ${ }^{1}$ and Barisi Samuel Penu ${ }^{2 *}$ \\ ${ }^{1}$ Department of Microbiology, Faculty of Science, Rivers State University, PMB 5058, \\ Nkpolu-Oroworukwo, Port Harcourt, Rivers State, Nigeria \\ ${ }^{2}$ Department of Science Laboratory Technology, School of Applied Sciences, Kenule Beeson \\ Saro-Wiwa Polytechnic, P. M. B. 20, Bori, Rivers State, Nigeria \\ *Corresponding author
}

\section{Keywords}

Bioremediation, Crude oil, Aspergillus clavatus, Pichia spp, Terrestrial soil

Article Info

Accepted:

07 February 2019 Available Online: 10 March 2019

\section{A B S T R A C T}

In Nigeria, crude oil pollution challenge of the terrestrial environment is very prevalent. Soil fungi play very important role in the degradation of organic materials, as well as agents of the biogeochemical cycles. Fungi have an advantage over bacteria due to their production of hyphae that can penetrate contaminated soil. The aim of this study was to evaluate the bioremediation potential of two fungal species: Aspergillus clavatus and Pichia spp. Crude oil contaminated soil samples were collected from Numuu Mitee, Kegbara-Dere community in Gokana Local Government Area of Rivers State; Nigeria. There were four experimental setups for the bioremediation study; Soil without organisms served as control(A), soil with Aspergillus clavatus alone (B), soil sample with Pichia spp. alone (C), while soil with Aspergillus clavatus and Pichia spp combined (D). Standard microbiological methods were used to analyze total heterotrophic and hydrocarbon utilizing fungi. The following physicochemical parameters; $\mathrm{pH}$, nitrate, phosphate, sulphate, and total hydrocarbon content (THC) were analysed for baseline and monitored every 7days for 28days. Molecular identification of the organisms was also carried out using $16 \mathrm{~S}$ rRNA amplification. The results of the baseline were as follows; $\mathrm{pH} 6.9$, nitrate $52 \mathrm{mg} / \mathrm{kg}$, phosphorus $149 \mathrm{mg} / \mathrm{kg}$, THC $8,006.58 \mathrm{mg} / \mathrm{kg}$, total heterotrophic fungi $3.8 \mathrm{x}$ $10^{4} \mathrm{cfu} / \mathrm{g}$ and hydrocarbon utilizing fungi $2.3 \times 10^{3} \mathrm{cfu} / \mathrm{g}$. The results showed that the physicochemical parameters decreased significantly during the study period. The results of bioremediation indicates that the total hydrocarbon content of the soil in day 1 was $8006.58 \mathrm{mg} / \mathrm{kg}$ but reduced in day 28 to $6799.74 \mathrm{mg} / \mathrm{kg}$ for setup A, $3309.21 \mathrm{mg} / \mathrm{kg}$ for B, $2835.53 \mathrm{mg} / \mathrm{kg}$ for $\mathrm{C}$ and $1572.37 \mathrm{mg} / \mathrm{kg}$ for D. The percentage THC loss was in this order: $\mathrm{D}>\mathrm{C}>\mathrm{B}>\mathrm{A}, 80.36 \%>64.59 \%>58.67 \%>15.07 \%$ respectively. This study reveals that using the Pichia species alone produced 64\% THC loss while Aspergillus clavatus alone produced $58.6 \%$ loss. Combined potential of Aspergillus clavatus and Pichia spp. produced $80 \%$ reduction in 28 days. This makes the consortium a more efficient option in bioremediation of crude oil contaminanted terrestrial soil. 


\section{Introduction}

The discovery and large scale production of crude oil in the Niger Delta region have exposed this region to great crude oil pollution challenge, due to the presence and activities of the petroleum industries. This region in the past years has experienced the devastating effect of oil spills into both the terrestrial and aquatic environments (Chikere and Ekwuabu, 2014). "The Petroleum Industry is a complex combination of interdependent operations, including exploration and production operations, the processing of the crude into consumer products, transportation and marketing activities (EGASPIN, 2018). The spill would also result from oil refining operations, equipment failure, accident, bunkering activities and also illegal crude oil refining activities (Douglas, 2018). "At each stage of these operations, gaseous, liquid and solid waste materials are produced and discharged. The presence of these wastes and their constituents may introduce changes to the quality of soil and sediment as well as underground water, thereby posing immediate or long-term unacceptable risks to plants, animals, human health and amenities" (EGASPIN, 2018). These can adversely affect the air, water and soil quality if not properly discharged and controlled. Crude oil pollution of terrestrial and aquatic ecosystems poses serious environmental concern today, in contemporary Nigeria and requires that clean up of the contaminated sites be carried out (Gesinde et al., 2008). The toxic properties of crude oil vary largely, in the light of their constituents as well as the existing organisms available during the contamination of the area (Obire and Anyanwu, 2009). Bioremediation has been demonstrated to be effective on various types of hydrocarbon spills during clean-up procedures over the years (Okoh, 2003). The major reason for the bioremediation process is to reduce the contaminant concentration to as low as reasonably and practically possible (Ibiene et al., 2011). It is an efficient and environmentally safe technique and inexpensive decontamination of such environments (Williams and Youngtor, 2017). In ensuring the restoration of the oil impacted soil, biological agents including fungi are applied to eat up the contaminants and detoxify the sites (Nester et al., 2004). The most common fungi which have been recorded as biodegraders belong to the following genera: Alternaria, Geotrichum, Candida, Aspergillus., Cephalosporium, Cladosporium, Fusarium, Gliocladium, Mucor, Polyporus, Rhizopus Saccharomyces, etc (Obire and Anyanwu, 2007). These fungal genera are well known due to their capability in the utilization of hydrocarbon as carbon and energy sources and producing oil degradability potential in indegenous microorganisms in the environment (Gesinde et al., 2008).

Owing to the problems associated with physical, mechanical and chemical methods of cleanup of contaminated environment, there is need for a safer and less expensive approach in remediation of polluted environments (Obire and Putheti, 2009). Recent studies involving bioremediation using fungi do not include bioremediation potentials of Aspergillus clavatus and Pichia species on crude oil pollution especially with reference to Kegbara-Dere in Gokana Local Government Area of Rivers State, and other parts of the Niger Delta (Obire and Anyanwu, 2009). The study area is in Ogoni land where oil exploration and production activities have been on for several decades. The area has suffered a lot of oil spills, due to lack of maintenance, damage to oil infrastructure as a result of oil bunkering and illegal refining activities resulting in polluted terrestrial soil environment. The polluted soil environment has not been remediated or in some areas partially remediated by natural attenuation (Chikere and Ekwuabu, 2014). This 
observation is supported by the UNEP report (2011) that stated that the pollution of the soil by petroleum hydrocarbon in this area is extensive in lands, swamps and sediments. It is against this backdrop, therefore, that this study is intended to undertake a comprehensive evaluation of the bioremediation potential of two fungi; Aspergillus clavatus and Pichia species.

\section{Materials and Methods}

\section{Description of study area}

Numuu Ledum in Kegbara-Dere (K-Dere) in Gokana Local Government Area of Rivers State, Nigeria is situated in the Niger Delta Area of Nigeria. K-Dere is bounded by BDere and Biara communities in the North; Kpor and Bomu in the South: Bera in the east while it is bounded in the West by Onne, in Eleme Local Government Area. It is situated between longitudes $7.01^{\circ}$ and $7.07^{\circ} \mathrm{E}$; and latitudes 4.08 and $4.2^{0} \mathrm{~N}$. The area experiences two distinct seasons; the rainy and dry seasons and it is characterized by high temperature, rainfall $(2000-2500 \mathrm{~mm} / \mathrm{yr})$, and high relative humidity. It is also characterized by poorly drained soil, low in nutrient due to the leaching of nutrient down the soil profile as a result of high rainfall. It is important to say that the inhabitants of Kegbara-Dere in Gokana local government area are renowned farmers

\section{Sample collection}

Soil samples were collected from four different points $1 \mathrm{~m}$ apart with a sterile hand trowel at a depth of 0 to $15 \mathrm{~cm}$. These soil samples were put together, mixed thoroughly to form a composite soil in polythene bags and transported to the Microbiology Laboratory of the Rivers State University. Baseline studies were immediately carried out on the soil samples (Douglas, 2018).

\section{Enumeration of total heterotrophic and hydrocarbon utilizing fungi}

Ten fold serial dilutions were carried out; $1 \mathrm{~g}$ of soil sample was dispensed into $9 \mathrm{ml}$ of normal saline, which was thoroughly mixed. Using a sterile pipette, $1 \mathrm{ml}$ of the mixture was transferred to another $9 \mathrm{ml}$ of normal saline and diluted to $10^{-4}$. Using the spread plate method, an aliquot of $0.1 \mathrm{ml}$ was transferred to an already prepared Sabouraud Dextrose Agar (SDA) and Mineral salt agar plates in triplicates.

SDA was used for the isolation and enumeration of total heterotrophic fungi (THF). Tetracycline was added to prevent bacterial growth and permitted selective isolation of yeasts and moulds (Harrigan and McCance, 1990). The plates were incubated at $28^{0} \mathrm{C}$ for 3 to 5days. Mineral salt media composition of Mills et al., (1978) as modified by Okpokwasili and Okorie (1988) was used. This media was composed of: $\mathrm{NaCl}, 10.0 \mathrm{~g}$; $\mathrm{MgSO}_{4} .7 \mathrm{H}_{2} \mathrm{O}, 0.42 \mathrm{~g} ; \mathrm{KCl}, 0.29 \mathrm{~g} ; \mathrm{KH}_{2} \mathrm{PO}_{4}$, $0.83 \mathrm{~g} ; \mathrm{Na}_{2} \mathrm{HPO}_{4}, 1.25 \mathrm{~g} ; \mathrm{NaNO}_{3}, 0.42 \mathrm{~g}$; agar, $20 \mathrm{~g}$; distilled water, $1 \mathrm{~L}$ and $\mathrm{pH}$ of 7.2. This medium was used for isolation, enumeration and preliminary identification of hydrocarbon-utilizing fungi (HUF). Vapour phase phase transfer method was used, were sterile filter paper (Whatman No 1) saturated with crude oil was placed inside the cover of the Petri dish, closed, inverted and incubated at $28^{0} \mathrm{C}$ for 5 to 7 days. Tetracycline was also added to prevent bacterial growth(Ibiene et al., 2011; Douglas, 2018). After incubation, the colonies that developed on the plates were counted and recorded as counts of total heterotrophic and hydrocarbon utilizing fungi, expressed as colony forming unit per gram. Discrete colonies were subcultured onto fresh medium for the development of pure isolates, which were stored on SDA slants for subsequent characterization and identification tests. 


\section{Identification of isolates}

Pure fungal isolates were further studied using lactophenol stain. A small portion of the fungal growth was picked with a wire loop and placed on clean and grease free slide. A drop of lactophenol was added and the preparation was covered with cover slip. The slide was observed under X10 and X40 objectives lenses (Obire et al., 2008). For the presumptive identification of fungal isolates, pure fungal cultures were observed while still on plates (macroscopic examination) and after wet mount in lacto-phenol on slides under the compound microscope. Observed characteristics were recorded and compared with the established identification key of Barnett and Hunter (1972).

\section{Molecular identification}

\section{DNA extraction, DNA Quantification, Internal Transcribed Spacer (ITS) amplification and sequencing}

DNA extraction was done on the pure fungi isolates from the soil sample with the aid of Zymo Research (ZR) fungal/bacteria DNA MiniPrep $^{\mathrm{TM}}$ (California, USA) extraction kit that was supplied by Inquaba, South Africa. The extracted genomic DNA was quantified using the Nanodrop 1000 spectrophotometer (Chikere and Fenibo, 2018). The PCR amplicons from the soil isolates were sequenced using a 3500 genetic analyzer.

The obtained sequence was edited using the bioinformatics algorithm Trace edit. Similar sequences were downloaded from the National Centre for Biotechnology Information (NCBI) database using BLASTN. These sequences were aligned using ClustalX. The evolutionary history was inferred using the neighbourhoodjoining method in MEGA 6.0 (Saitou and Nei, 1987). The bootstrap consensus tree inferred from 500 replicates (Felsenstein, 1985) is taken to represent the evolutionary history of the taxa analyzed. The evolutionary distances were computed using the Jukes-Cantor method (Jukes and Cantor, 1969).

\section{Physicochemical analyses}

The following physicochemical parameters were analysed; the soil temperature, $\mathrm{pH}$, nitrogen, phosphorus, sulphate and total petroleum hydrocarbon (TPH) according to the procedure in Standard Methods of water and waste (APHA, 2008).

\section{Total hydrocarbon content determination}

This was done in the extraction flask, were $10 \mathrm{grams}$ of the soil sample was put, $50 \mathrm{ml}$ of n-hexane was added for the extraction of petroleum hydrocarbon was done using cold extraction method with ASTM D-3694 heavy machine for 1 hour. The extraction process was repeated until a colourless solution was obtained (Ibiene et al., 2011).

\section{Bioremediation experimental set up}

The terrestrial soil samples taken from "Numuu Ledum" were weighed using top load balance. Two hundred and fifty grams $(250 \mathrm{~g})$ of soil samples were put into four (4) sets of clay pots (labeled A to D). From the standard inoculums prepared with each isolate, using a graduated measuring cylinder, $100 \mathrm{ml}$ of organisms were added to each setup. Soil without organisms served as control(A), soil with Aspergillus clavatus (B), soil sample with Pichia $\operatorname{spp}(\mathrm{C})$, while soil with Aspergillus clavatus and Pichia spp (D) (Nrior and Wosa, 2016). The experimental setup were allowed to stand for 28 days at room temperature and samples taken out for both microbiological (THF and HUF) and physicochemical parameters $(\mathrm{pH}, \quad$ temperature, nitrate, phosphate, sulphate, and THC) every 7days (Table 1). 


\section{Results and Discussion}

The results of the baseline are shown in Table 2. The $\mathrm{pH}$ of the soil sample was 6.9. Nitrate, phosphate and THC were $52.0 \mathrm{mg} / \mathrm{kg}$, $149.0 \mathrm{mg} / \mathrm{kg}$ and $8,006.58 \mathrm{mg} / \mathrm{kg}$, respectively. The total heterotrophic fungi (THF) and hydrocarbon utilizing fungi (HUF) counts were $3.8 \times 10^{4} \mathrm{cfu} / \mathrm{g}$ and $2.3 \times 10^{3} \mathrm{cfu} / \mathrm{g}$, respectively. The THC concentration of $8,006.56 \mathrm{mg} / \mathrm{kg}$ is above the Department of Petroleum Resources (DPR) approved intervention value of $5,000 \mathrm{mg} / \mathrm{kg}$ (EGASPIN, 2018), hence there is need for remediation programme, to restore the soil back. Figure 1 shows the phylogenic tree of the isolates.

\section{Microbiological analyses}

Table 2 shows the results of logarithm to base ten counts of A. clavatus and Pichia spp on crude oil polluted terrestrial soil during 28days monitoring. At day 1, A. clavatus population was least $(1.60 \pm 0.05)$ while consortium had the highest population growth (1.78 \pm 0.18$)$. From day 7 to day 14, Aspergillus growth ranged from $1.75 \pm 0.03$ to $1.76 \pm 0.14$ while that of Pichia was $1.79 \pm 0.00$ to $1.84 \pm 0.01$, showing an increased population with increase in time. From day 21 to day 28 , the population of Aspergillus clavatus, Pichia spp. and consortium ranged from $1.82 \pm 0.11,1.84 \pm 0.03$ to $1.90 \pm 0.02$, respectively.

Figure 2 shows the total hydrocarbon content of the treated soil using A. clavatus and Pichia spp. The THC was $8006.58 \mathrm{mg} / \mathrm{kg}$ on day 1 which reduced to $4519.74 \mathrm{mg} / \mathrm{kg}$ at day 28 . Figure 3 shows the bioremediation rate at day 28 of the soil using A. clavatus and Pichia spp. The results indicated that crude oil polluted terrestrial soil had the least THC of $6799.74 \mathrm{mg} / \mathrm{kg}$, followed by A. clavatus $3309.21 \mathrm{mg} / \mathrm{kg}$. Pichia spp showed a bioremediation rate of $2835.53 \mathrm{mg} / \mathrm{kg}$ while consortium had the highest bioremediation rate $(1572.37 \mathrm{mg} / \mathrm{kg})$ at day 28 . Figure 4, shows the percentage bioremediation potential of crude oil polluted terrestrial soil using $A$. clavatus and Pichia spp. and the percentages were: $15.07 \%<58.67 \%<64.59 \%<80.36 \%$ for Control, A. clavatus, Pichia spp. and the consortium, respectively.

\section{Results of physicochemical parameters}

Results of the physicochemical parameters during the 28days bioremediation monitoring are shown in Table 3 below. Temperature of the terrestrial soil was $28^{0} \mathrm{C}$ between day 1 and day 28 for the control set up. There were slight changes in temperature in the soil treated with Pichia species as well as Aspergillus clavatus (B) from $30^{\circ} \mathrm{C}$ to $28^{\circ} \mathrm{C}$ for Pichia $\operatorname{spp}(\mathrm{C})$ and $31^{\circ} \mathrm{C}$ to $28^{\circ} \mathrm{C}$ for A. clavatus. The temperature of the consortium set up D were: $30^{\circ} \mathrm{C}$ and $27^{\circ} \mathrm{C}$ for days 1 and day $28^{\circ} \mathrm{C}$ respectively. Nitrate content of control varied from $44 \mathrm{mg} / \mathrm{kg}$ to $37 \mathrm{mg} / \mathrm{kg}$ from day 1 to day 28 . Nitrate content varied from $29 \mathrm{mg} / \mathrm{kg}$ at day 28 in consortium to $52 \mathrm{mg} / \mathrm{kg}$ at day 1 in $A$. clavatus. Phosphorus content ranged from $105 \mathrm{mg} / \mathrm{kg}$ at day 28 in the control set up to $163 \mathrm{mg} / \mathrm{kg}$ at day 1 in A. clavatus. Sulphate values ranged from 273 to $336 \mathrm{mg} / \mathrm{kg}$ (consortium): 310 to $344 \mathrm{mg} / \mathrm{kg}$ (A. clavatus): 312 to $335 \mathrm{mg} / \mathrm{kg}$ (Pichia spp): and 325 to $335 \mathrm{mg} / \mathrm{kg}$ (control). A decrease in the concentrations of these nutrients was observed with time.

Comparing the log counts of Aspergillus clavatus and Pichia species in the soil sample (Table 4), revealed that the counts in the consortium were higher than those of the other setups. This implies that the oil was more utilized by the combined organisms (consortium). Obire and Putheti (2009) suggested that microbial consortium degrades synthetic petroleum mixture faster than single organisms. Similar results were obtained by 
Nrior and Wosa (2016). Another reason why Aspergillus clavatus and Pichia spp. tend to sporulate better in oil contaminated environment may be as a result of the hydrocarbon utilising enzymes produced by these organisms (Chikere and Azubuike, 2014). Crude oil has been reported by Nrior and Odokuma (2017) to be more tolerant to microorganisms, especially fungi having a higher tolerance to the toxicity of hydrocarbons due to their physiological adaptation to such variations in the environment and they have the mechanism for the elimination of oil spill from the environment.

The results of the megablast search for the $16 \mathrm{~S}$ rRNA sequence similarity gave the match from the National Centre for Biotechnology Information (NCBI) database. Figure 1 is the phylogenic tree showing the percentage similarity of $100 \%$, with respect to other genera. The evolutionary distances obtained are in agreement with the 16S rRNA phylogenic order of the isolates within the genera which shows a high level of similarity to the genus than other genera within (Chikere and Fenibo, 2018).

Results of the physicochemical analyses (Table 3) indicated that hydrogen ion concentration $(\mathrm{pH})$ of the soil samples during the monitoring period ranged from 6.90 to 7.79 showing the soil, is slightly acidic. The near neutral $\mathrm{pH}$ provides buffering property which may have contributed to the survival of the test organisms. This confirmed that Aspergillus clavatus and most fungi grow very well at neutral and slightly acidic $\mathrm{pH}$. Chikere and Ekwuabu, (2014), reported that $\mathrm{pH}$ range optimal for biodegradation is $6-7$. Temperature varies from $28^{0} \mathrm{C}$ to $31^{0} \mathrm{C}$ in the soil which is typical of tropical soils (Maharshi and Thaker, 2012). Moreover, Aspergillus clavatus have been reported severally to have a certain ability to alter the temperature of its environment to favor its growth. Aspergillus clavatus can modify the temperature and $\mathrm{pH}$ of their environment by secreting acids such as butyrate, oxalate, malate, citrate, gluconate, and succinate (Maharshi and Thaker, 2012). Aspergillus clavatus sporulates at an optimum temperature of $31^{\circ} \mathrm{C}$ (Low et al., 2011) and the consortium thriving at the lowest temperature of $27^{\circ} \mathrm{C}$ towards day 28. Shehu and Bello (2011) also, reported that Aspergillus clavatus thrives at higher temperatures, even as high as $40^{\circ} \mathrm{C}$. The concentration of nitrate present in the soil was high enough to support microbial growth. Although microorganisms are ubiquitous in nature, they however thrive better under the availability of nutrients (Prescott et al., 2005). Nutrients are limiting factors for successful biodegradation of crude oil pollutants especially nitrogen, phosphorus (Chikere and Ekwuabu, 2014). However, the reduction in the nitrate, phosphate and sulphate concentrations in the course of the bioremediation monitoring is an indication that these nutrients were being used up by the organisms as utilize the hydrocarbon source (Okpokwasili and Odokuma, 1990). The results of the Total Hydrocarbon Content (THC-mg/kg) from the bioremediation set up (Fig. 2), shows that there was a reduction in the $\mathrm{THC}-\mathrm{mg} / \mathrm{kg}$ for Control from $8006.58 \mathrm{mg} / \mathrm{kg}$ to $6799.74 \mathrm{mg} / \mathrm{kg}$ on the $28^{\text {th }}$ day of monitoring (Fig. 2). The final THC level, from the different set ups on day 28, were: $3309.21 \mathrm{mg} / \mathrm{kg}$ (Aspergillus clavatus), $2835.53 \mathrm{mg} / \mathrm{kg} \quad$ (Pichia species), and $1572.37 / \mathrm{kg}$ (consortium). This result implies that both Aspergillus clavatus and Pichia spp have certain bioremediation potentials that are enhanced when they are used together, as they could utilize crude oil/petroleum products as their sole carbon source. This ability to degrade crude oil may be due to cometabolism (Chikere and Azubuike, 2014). Aspergillus clavatus have been reported to possess $100 \%$ bioremediation potential (Mbachu et al., 2016). 
Table.1 Bioremediation experimental setup

\begin{tabular}{|l|l|}
\hline Pots & Constituents \\
\hline A & $\begin{array}{l}250 \mathrm{~g} \text { of sterile Soil, no organism was } \\
\text { added(control) }\end{array}$ \\
\hline B & $250 \mathrm{~g}+100 \mathrm{ml}$ of Aspergillus clavatus \\
\hline C & $250 \mathrm{~g}+100 \mathrm{ml}$ of Pichia spp \\
\hline D & $\begin{array}{l}250 \mathrm{~g}+50 \mathrm{ml} \text { of Aspergillus clavatus }+50 \mathrm{ml} \text { of } \\
\text { Pichia } \mathrm{spp}\end{array}$ \\
\hline
\end{tabular}

Table.2 Results of baseline properties of the soil sample

\begin{tabular}{|l|l|}
\hline Parameters & Values \\
\hline pH & 6.9 \\
\hline Nitrate $(\mathbf{m g} / \mathbf{k g})$ & 52.0 \\
\hline Phosphate(mg/kg) & 149.0 \\
\hline THC(mg/kg) & $8,006.58$ \\
\hline Total Heterotrophic Fungi(cfu/g) & $3.8 \times 10^{4}$ \\
\hline Hydrocarbon utilizing Fungi(cfu/g) & $2.3 \times 10^{3}$ \\
\hline
\end{tabular}

The following fungal genera were identified; Alternaria, Geotrichum, Candida, Aspergillus, Cladosporium, Fusarium, Penicillum, Mucor, Rhizopus, and Saccharomyces

Table.3 Physico-chemical parameters of terrestrial soil sample monitoring

\begin{tabular}{|c|c|c|c|c|c|c|c|c|c|c|c|}
\hline \multicolumn{3}{|l|}{ Ctrl } & \multicolumn{3}{|c|}{ Pichia spp } & \multicolumn{3}{|c|}{ Aspergillus clavatus } & \multicolumn{3}{|c|}{ PIC + ASP } \\
\hline Day 1 & Day 28 & Diff & $\begin{array}{l}\mathrm{Da} \\
\text { y } 1\end{array}$ & $\begin{array}{l}\text { Day } \\
28\end{array}$ & $\begin{array}{l}\text { Dif } \\
\mathrm{f}\end{array}$ & $\begin{array}{l}\text { Day } \\
1\end{array}$ & $\begin{array}{l}\text { Day } \\
28\end{array}$ & Diff. & Day 1 & Day 28 & 3 Diff. \\
\hline \multicolumn{12}{|c|}{ Temperature $\left({ }^{0} \mathrm{C}\right)$} \\
\hline 28 & 28 & 0 & 30 & 28 & -2 & 31 & 28 & -3 & 30 & 27 & -3 \\
\hline \multicolumn{12}{|c|}{ Nitrate (mg/kg) } \\
\hline 44 & 37 & -7 & 51 & 38 & -13 & 52 & 39 & -13 & 57 & 29 & -28 \\
\hline \multicolumn{12}{|c|}{ Phosphate (mg/kg) } \\
\hline 149 & 105 & -44 & 159 & 144 & -15 & 163 & 136 & -27 & 160 & 123 & -37 \\
\hline \multicolumn{12}{|c|}{ Sulphate (mg/kg) } \\
\hline 335 & 325 & -10 & 335 & 312 & -23 & 344 & 310 & -34 & 336 & 273 & -63 \\
\hline
\end{tabular}

Key: $\operatorname{Ctrl}=$ Crude oil polluted Terrestrial Soil without organisms; PIC+ASP $=$ Pichia spp plus Aspergillus clavatus (consortium). DIFF $=$ Difference 
Table.4 Log10 counts (cfu/g) of Aspergillus clavatus and Pichia species in the Soil during 28days Monitoring

\begin{tabular}{|l|l|l|l|l|}
\hline Days & Log Ctrl & Log ASP & Log PIC & $\begin{array}{l}\text { Log PIC } \\
\text { ASP }\end{array}$ \\
\hline 1 & $1.58 \pm 0.11^{\mathrm{a}}$ & $1.60 \pm 0.05^{\mathrm{a}}$ & $1.68 \pm 0.04^{\mathrm{a}}$ & $1.78 \pm 0.18^{\mathrm{a}}$ \\
\hline 7 & $1.59 \pm 0.13^{\mathrm{a}}$ & $1.75 \pm 0.032^{\mathrm{a}}$ & $1.79 \pm 0.01^{\mathrm{a}}$ & $1.92 \pm 0.04^{\mathrm{a}}$ \\
\hline 14 & $1.68 \pm 0.3^{\mathrm{a}}$ & $1.76 \pm 0.14^{\mathrm{a}}$ & $1.84 \pm 0.01^{\mathrm{a}}$ & $1.93 \pm 0.03^{\mathrm{a}}$ \\
\hline 21 & $1.75 \pm 0.05^{\mathrm{a}}$ & $1.80 \pm 0.06^{\mathrm{a}}$ & $1.80 \pm 0.06^{\mathrm{a}}$ & $1.90 \pm 0.03^{\mathrm{a}}$ \\
\hline 28 & $1.81 \pm 0.11^{\mathrm{a}}$ & $1.82 \pm 0.11^{\mathrm{a}}$ & $1.84 \pm 0.03^{\mathrm{a}}$ & $1.90 \pm 0.02^{\mathrm{a}}$ \\
\hline
\end{tabular}

Means with the same alphabet across columns show no significant difference $(p>0.05)$

Key: Ctrl $=$ Crude Oil Polluted Terrestrial Soil without Organisms; ASP $=$ Crude Oil Polluted Terrestrial Soil with Aspergillus clavatus; PIC = Crude Oil Polluted Terrestrial Soil with Pichia spp.; PIC + ASP = Crude Oil Polluted Terrestrial Soil with Aspergillus clavatus and Pichia spp.

Fig.1 Phylogenetic Tree of Aspergillus clavatus and Pichia spp.

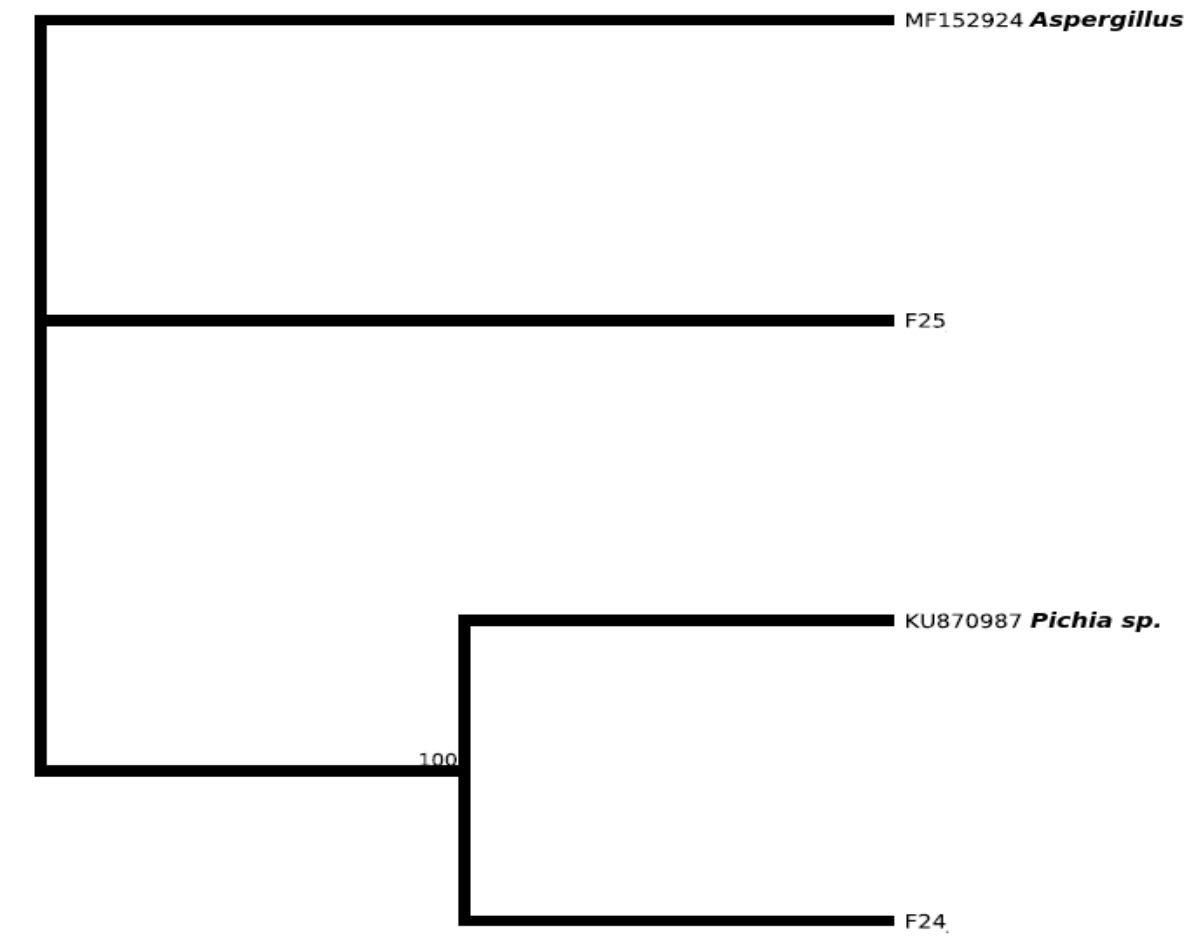


Fig.2 Total Hydrocarbon Content (THC-mg/kg) of Bioremediated crude oil polluted terrestrial soil using Aspergillus clavatus and Pichia species during 28 days monitoring

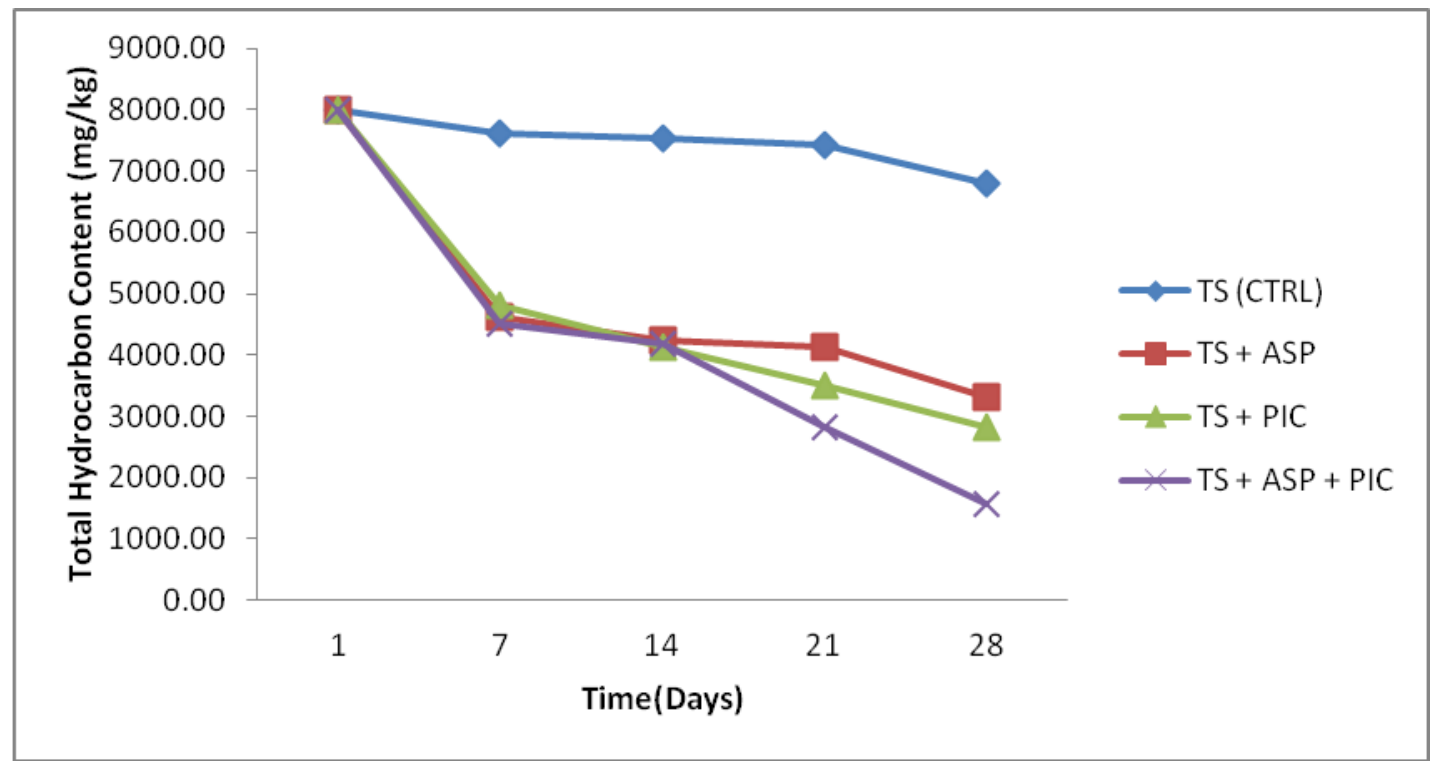

Key: TS $($ CTRL) $=$ Crude Oil Polluted Terrestrial Soil without Organisms; TS+ASP $=$ Crude Oil Polluted

Terrestrial Soil with Aspergillus clavatus; TS+PIC = Crude Oil Polluted Terrestrial Soil Pichia spp; TS+ASP+PIC = Crude Oil Polluted Terrestrial Soil with Aspergillus clavatus and Pichia spp.

Fig.3 Bioremediation rate $(\mathrm{mg} / \mathrm{kg})$ of crude oil polluted terrestrial soil using Aspergillus clavatus and Pichia species on day 28 of monitoring

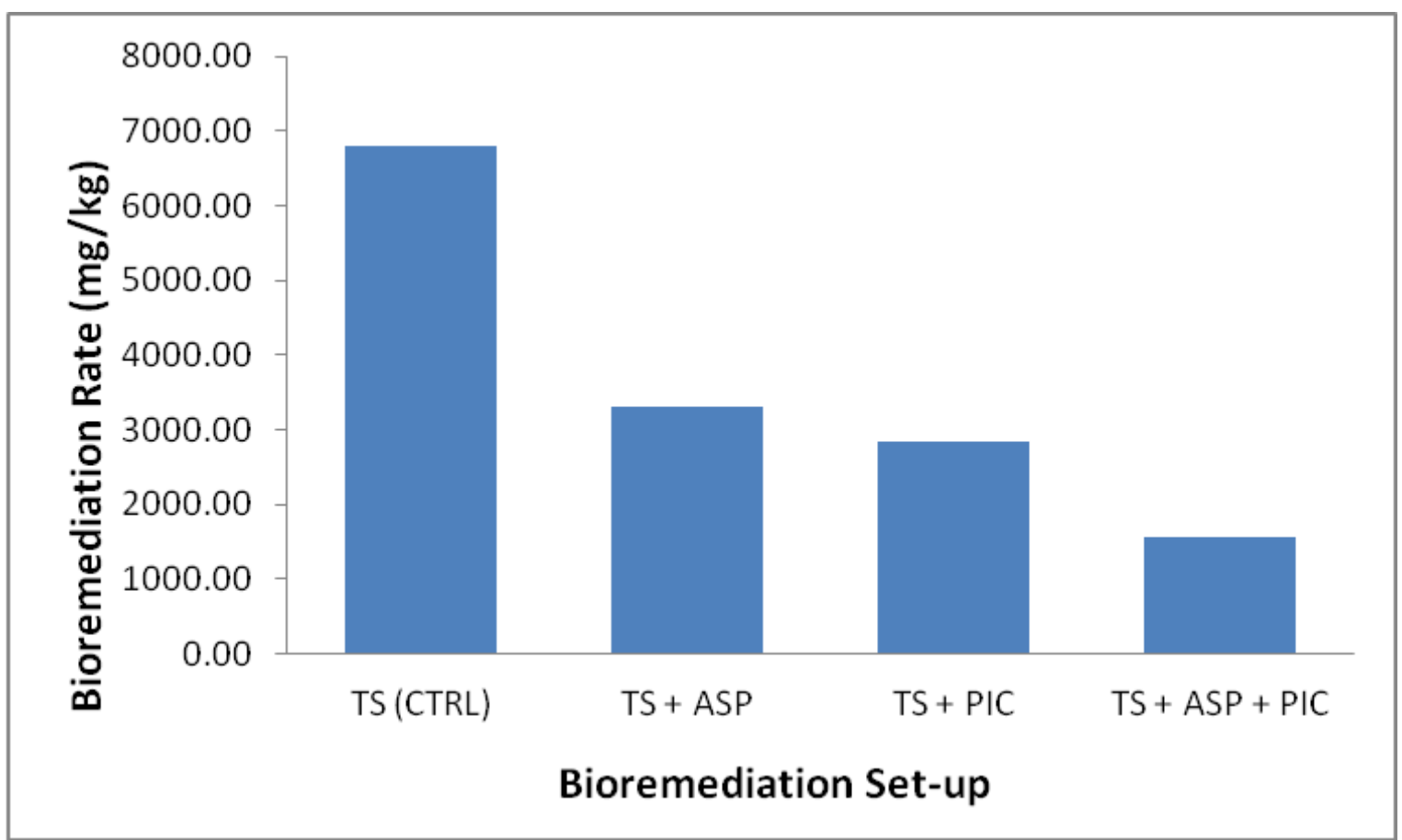

Key: TS $($ CTRL) $=$ Crude Oil Polluted Terrestrial Soil without Organisms; TS+ASP = Crude Oil Polluted Terrestrial Soil with Aspergillus clavatus; TS+PIC = Crude Oil Polluted Terrestrial Soil Pichia spp; TS+ASP+PIC = Crude Oil Polluted Terrestrial Soil with Aspergillus clavatus and Pichia spp. 
Fig.4 Percentage bioremediation potential of Aspergillus clavatus and Pichia spp. on crude oil polluted terrestrial soil on day 28 of monitoring

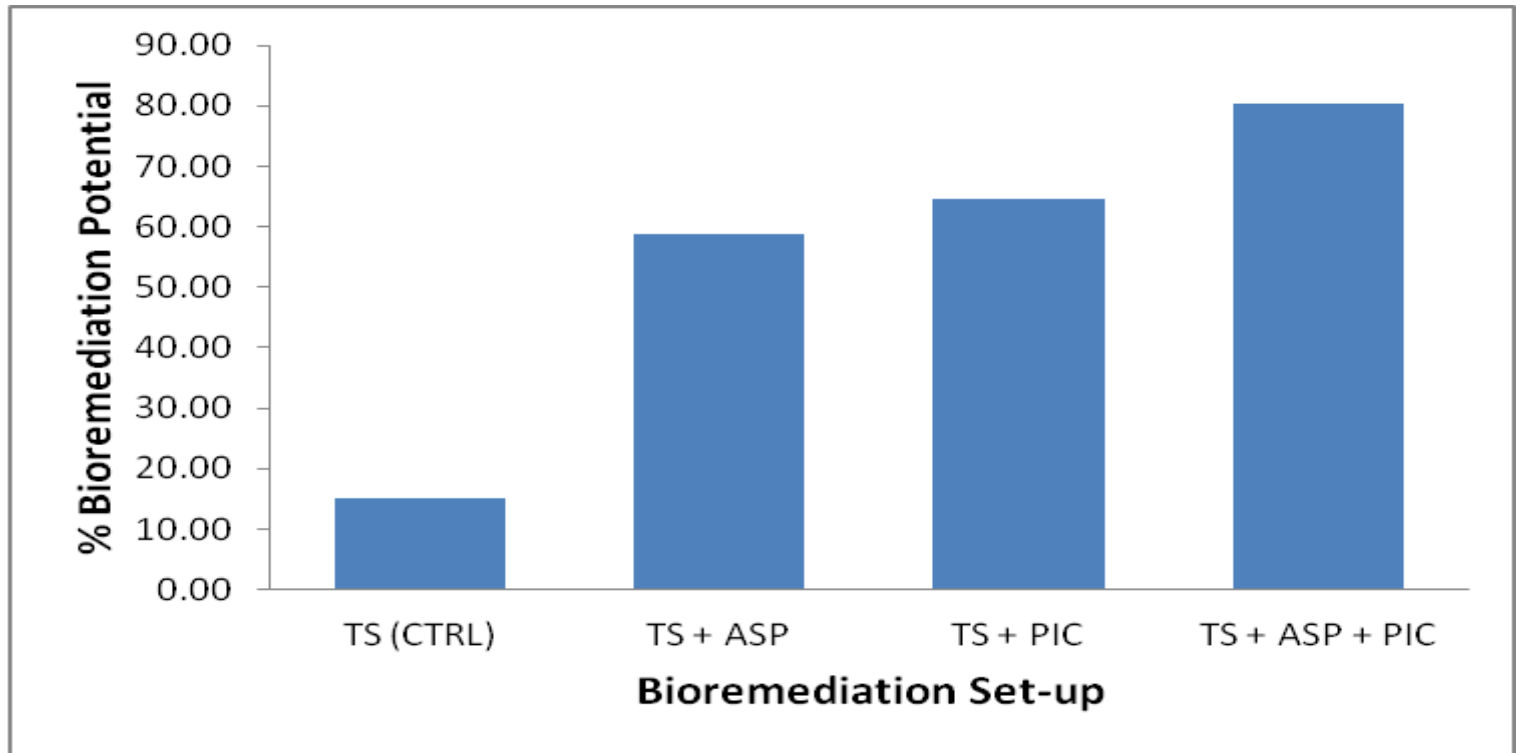

Key: TS $($ CTRL $)=$ Crude Oil Polluted Terrestrial Soil without Organisms; TS+ASP $=$ Crude Oil Polluted Terrestrial Soil with Aspergillus clavatus; TS+PIC = Crude Oil Polluted Terrestrial Soil Pichia spp; TS+ASP+PIC = Crude Oil Polluted Terrestrial Soil with Aspergillus clavatus and Pichia spp.

The yeast, Pichia spp has also been reported to be a potent bioremediation organism (Ortansa et al., 2010). The Fungi, Aspergillus and yeast, Pichia have been reported to readily degrade hydrocarbon (Atlas 1995). Fungal isolates are regularly used to clean up oil spills owing to the bioremediation ability in tropical soil (Chaillan et al., 2004). The percentage bioremediation potentials of the fungi (Fig. 4) were as follows: soil without organisms (A), soil plus Aspergillus clavatus,(B), soil with Pichia spp.(C) and soil plus consortium(D), $\quad 15.07 \% \quad<58.67 \%$ $<64.59 \%<80.36 \%$.

The results indicate that the joint potential of Aspergillus clavatus and Pichia spp have the highest percentage bioremediation potential. The results of the primary degradation of the crude oil or the bioremediation potential of the organisms according to OECD (2001), is the alteration, structural change (transformation) in the chemical constituents of the substance brought about by biological actions of the microorganisms, resulting in the loss of a specific property.

In conclusion, the identification and selection of potentially effective microorganisms immensely contributes to the successful bioremediation process of crude oil polluted terrestrial soil. To achieve the above, fungal isolates were applied on petroleum impacted soil. The use of fungal consortium (Aspergillus clavatus and Pichia species) in the presence of conducive environmental factors like optimum temperature, availability of moisture, and nutrients play crucial roles in the process of bioremediation. This study reveals that using the Pichia species alone produced $64 \%$ THC loss while Aspergillus clavatus alone produced $58.6 \%$ loss. Combined potential of Aspergillus clavatus and Pichia spp. produced $80 \%$ reduction of THC in 28days. This makes the consortium a more efficient option in bioremediation of crude oil contaminanted terrestrial soil. 


\section{References}

Altas, R.M. (1995). Petroleum biodegradation and oil spill bioremediation. Mar Pollut Bull 31:178-182.

Atagana, H.I., Haynes, R.J., and Wallis, F.W. (2006). Fungal bioremediation of creosote-contaminated soil: A laboratory scale Bioremediation study using indigenous soil fungi. Water Air Soil Pollution, 172, 201-219.

APHA. (2008). Standard methods for the examination of water and waste water 20th(ed), Washington D.C. 1213pp.

Barnett, H. L. and Hunter, B. B., (1972). Illustrated Genera of Fungi Imperfecti. 3rd. Ed., Burgess Publication Co., Minneapolis.

Chaillan, F., Le Flèche, A., Bury, E., Phantavong, Y.H., Grimont, P., Saliot, A. and Oudot, J. (2004). Identification and biodegradation potential of tropical aerobic hydrocarbon-degrading microorganisms. Research in Microbiology, 155(7), 587-595.

Chikere, C.B., and Azubuike, C.C. (2014). Characterization of hydrocarbon utilizing fungi from hydrocarbon polluted sediments and water. Nigerian journal of Biotechnology, 27:49-54.

Chikere, C. B. and Ekwuabu, C. B. (2014). Culture-dependent characterization of hydrocarbon utilizing bacteria in selected crude oil-impacted sites in Bodo, Ogoniland, Nigeria. African Journal of Environmental Science and Biotechnology. 8(6): 401-406.

Chikere, C. B. and Fenibo, E. O. (2018) Distribution of PAH-ring hydroxylating dioxygenase genes in bacteria isolated from two illegal oil refining sites in the Niger Delta, Nigeria. Scientific Africa. 113

Douglas, S. I. (2018). Effect of illegally Refined Crude Oil (Kpo-Fire) Residue on Soil Fungi. International Journal of current microbiology and Applied Sciences, 7(12): 3309-3316.

EGASPIN (Environmental Guidelines and
Standards for the Petroleum Industry in Nigeria) (2018). $3^{\text {rd }}$ Issued by the Department of Petroleum Resources (DPR), Lagos; of the Nigerian Ministry of Petroleum Resources.

Gesinde, A.F., Agbo, E.B., Agho, M.O., Dike, E.F.C. (2008). Bioremediation of Some Nigerian and Arabian Crude Oils by Fungal Isolates. International Journal of Pure and Applied Sciences, 2:37-44.

Harrigan, W.F. and McCance, M.E. (1990). Laboratory Methods in Food and Diary Microbiology. Academic Press, London.

Jukes, T.H. and Cantor, C.R. (1969). Evolution of protein molecules. In Munro $\mathrm{HN}$, editor, Mammalian Protein Metabolism, pp. 21-132, Academic Press, New York.

Low, S.W., Dannemiller, K., Yao, M., Yamamoto, N. and Peccia, J. (2011). The Allergenicity of Aspergillus fumigatus conidia is influenced by growth temperature. Fungal Biology, 115(7): 1000-1016.

Maharshi, A.R and Thaker, V.S. (2012). Growth and development of plant pathogenic fungi in define media. European Journal of Experimental Biology, 2(1):44-54.

Mbachu, A.E., Chukwura, E.I., Mbachu, N.A. (2016). Isolation and characterization of hydrpcarbon degrading fungi from used (spent) engine oil polluted soil and their use for Polycyclic Aromatic Hydrocarbons (PAHs) Degradation. Universal journal of Microbiology Research 4(1): 31-37.

Nester, E. W., Anderson, D. G., Roberts, Jr., C. E., Pearsall, N. N. and Nester, M. T. (2004). Microbiology: A human perspective. $4^{\text {th }}$ ed., New York: McGrawHill. Pp. 797-800.

Nrior, R.R., and Odokuma, L. (2017). Toxicity of oil spill dispersant on fresh water fish Poeciliopsis occidentalis and bacterial Nitrobacter species. Toxicology Digest 1(2): 113-130.

Nrior, R. R. and Wosa, C. (2016). Biodegradation of oil spill dispersant in brackish water ecosystem of the Niger 
Delta, Nigeria. Journal of International Society of Comparative Education, Science and Technology (ICEST) 3(1):187-201.

Ibiene, A. A., Orji, F. A., Ezidi, C. O. and Ngwobia1, C. L. (2011). Bioremediation of hydrocarbon contaminated soil in the Niger Delta using spent mushroom compost and other organic wastes. Nigerian Journal of Agriculture, Food and Environment, 7(3): 1-7.

Obire, O, and Anyanwu, E.C. (2009). Impact of various concentrations of crude oil on fungi populations of soil. International Journal of Environmental Science Tecchnology, 6, 21-218.

Obire, O., Anyanwu, E., and Okigbo, R. (2008). Saprophytic and Crude oil Degrading fungi from Cow dung and Poultry droppings as Bioremediating Agents. Journal of Agricultural Technology.

Obire, O. and Putheti, R.R. (2009). Fungi in bioremediation of oil polluted environments. Year of Energy 2009, Sigma XI, The Scientifc Research Society. $1-9$.

OECD (2001). OECD Guideline for testing of chemicals. Draft Document, proposal for a new Guideline 302D, 1-11.

Okoh, A.I. (2003). Biodegradation of Bonny light crude oil in soil microcosm by some bacterial strains isolated from crude oil flow stations saver pits in Nigeria. African Journal of Biotechnology. 2(5): 104-108.

Okpokwasili, G.C., and Odokuma, L.O. (1990). Effect of salinity on biodegradation of oil spill dispersant. Waste Management. 10: 141-146.

Ortansa, C., Ileana, S., Raluca, G., Ana-Maria, T. And Tatiana, V. (2010). Insights on yeast bioremediation processes. Romanian Biotechnological Letters, 15, (2), 5066-5071.

Prescott, L.M; Harley, J.P. and Klein, D.A. (2005). Microbiology. 6th ed. McGraw Hill, $\quad$ London. 135-140.

Saitou N. and Nei M. (1987). The neighborjoining method: A new method for reconstructing phylogenetic trees. Molecular Biology and Evolution 4:406425.

Shehu, K.T., and Bello, M.T. (2011). Effect of environmental factors on the growth of Aspergillus species associated with stored millet grains in Sokoto. Nigerian journal of Basic and Applied Science 19(2):218223.

Solomon, L., Ogugbue, C. J. and Okpokwasili, G. C. (2018). Inherent Bacterial Diversity and Enhanced Bioremediation of an Aged Crude Oil-contaminated Soil in Yorla, Ogoni Land Using Composted Plant Biomass. Journal of Advances in Microbiology, 9(3): 1-11.

United Nations Environmental Programme (UNEP) (2011). Environmental Assessment of Ogoniland, UNEP Assessment Report.1:65-66.

Williams, J. O. and Youngtor, T.P. (2017). Remediaton of pesticide-polluted River using Anabaena and Nostoc spp. Journal of Environmental Science, Toxicology and Food Technology, 11(7), 71-76.

\section{How to cite this article:}

Salome Ibietela Douglas and Barisi Samuel-Penu. 2019. Bioremediation of Crude Oil Polluted Terrestrial Soil using Aspergillus clavatus and Pichia spp. Int.J.Curr.Microbiol.App.Sci. 8(03): 733-744. doi: https://doi.org/10.20546/ijcmas.2019.803.090 